\title{
Defining ethical challenge(s) in healthcare research: a rapid review
}

\author{
Guy Schofield ${ }^{1,3^{*}}$ (D) Mariana Dittborn ${ }^{2}$, Lucy Ellen Selman ${ }^{3}$ (i) and Richard Huxtable ${ }^{1}$
}

\begin{abstract}
Background: Despite its ubiquity in academic research, the phrase 'ethical challenge(s)' appears to lack an agreed definition. A lack of a definition risks introducing confusion or avoidable bias. Conceptual clarity is a key component of research, both theoretical and empirical. Using a rapid review methodology, we sought to review definitions of 'ethical challenge(s)' and closely related terms as used in current healthcare research literature.

Methods: Rapid review to identify peer-reviewed reports examining 'ethical challenge(s)' in any context, extracting data on definitions of 'ethical challenge(s)' in use, and synonymous use of closely related terms in the general manuscript text. Data were analysed using content analysis. Four databases (MEDLINE, Philosopher's Index, EMBASE, CINAHL) were searched from April 2016 to April 2021.
\end{abstract}

Results: 393 records were screened, with 72 studies eligible and included: 53 empirical studies, 17 structured reviews and 2 review protocols. 12/72 (17\%) contained an explicit definition of 'ethical challenge(s), two of which were shared, resulting in 11 unique definitions. Within these 11 definitions, four approaches were identified: definition through concepts; reference to moral conflict, moral uncertainty or difficult choices; definition by participants; and challenges linked to emotional or moral distress. Each definition contained one or more of these approaches, but none contained all four. 68/72 (94\%) included studies used terms closely related to synonymously refer to 'ethical challenge(s)' within their manuscript text, with 32 different terms identified and between one and eight different terms mentioned per study.

Conclusions: Only 12/72 studies contained an explicit definition of 'ethical challenge(s)', with significant variety in scope and complexity. This variation risks confusion and biasing data analysis and results, reducing confidence in research findings. Further work on establishing acceptable definitional content is needed to inform future bioethics research.

Keywords: Ethical challenges, Rapid review, Empirical bioethics, Moral dilemmas

\section{Background}

Methodological rigour within research is a cornerstone in the production of high-quality findings and recommendations. Across the range of empirical methodologies, a broad collection of protocol development tools, methodology guidelines, and reporting guidelines have

\footnotetext{
*Correspondence: guy.schofield@bristol.ac.uk

${ }^{1}$ Centre for Ethics in Medicine, Population Health Sciences, Bristol

Medical School, University of Bristol, Bristol BS8 2PS, UK

Full list of author information is available at the end of the article
}

been developed and evidence of their use is increasingly required by journals [1-6]. Within both empirical bioethics and descriptive ethics, there has been an accompanying increase in the acknowledgment of the importance of methodological rigour in the empirical elements, including within the recent consensus statement on quality standards in empirical bioethics research by Ives et al. [7-9]. Aligned with this aim for rigour, definitional clarity of key terms used within a research project is a component of research quality $[10,11]$. Improving the quality 
of empirical bioethics is also itself an ethical imperative [9].

We recently conducted a systematic review examining 'ethical challenges' as reported by specialist palliative care practitioners [12]. Our review, alongside our initial scoping search findings and reading of the literature, suggested that, although many authors use the term 'ethical challenge(s)' in empirical ethics research, there appeared to be no commonly described or accepted definition. Furthermore, papers retrieved rarely defined 'ethical challenge(s)' explicitly, which has also been noted by other researchers examining other topic areas [13-15]. Our review further suggested that authors frequently use terms closely related to 'ethical challenge(s)'-such as 'moral dilemmas' or 'ethical issues'-interchangeably with 'ethical challenge(s)' throughout manuscripts, rather than staying with the original term. Research shows that non-philosophers may understand these related terms in heterogeneous ways which may additionally affect understanding of texts across different readerships $[16,17]$.

Without a clear definition of an ethical challenge, each researcher must use individual judgement to ascertain whether they have identified an instance of one within their dataset. This potentially generates an unnecessary source of bias, particularly if multiple researchers are involved in data collection, extraction, or analysis. This risks generating misleading ethical analyses, evaluations, or recommendations. Additionally, and more broadly, if primary studies do not define the term, then work based on these-such as systematic reviews of individual studies or those undertaking secondary data analysis-may unknowingly compare different phenomena without a mechanism for mitigating the effects this introduces.

In the hope of prompting a debate on this topic, we therefore undertook a rapid review, which aimed to explore existing definitions of "ethical challenge(s)" and the use of other closely related terms within recent empirical healthcare ethics literature.

\section{Methods}

We conducted a rapid review examining the usage of the term 'ethical challenge(s)' over the last 5 years in published research articles, in order to identify and summarise if, and how, the term was defined. As a secondary aim, we examined authors' uses of closely related alternative terms within the included article texts separate to their use within any explicit definitions that may be present.

Rapid reviews use abridged systematic review methodology to understand the evidence base on a particular topic in a time and resource efficient manner [18-22]. Comparative reviews of topics in which both a rapid review and a systematic review had been undertaken demonstrated that the overall conclusions were similar, although rapid reviews were less likely to contain social and economic data, and systematic reviews contained more detailed recommendations [18-20, 23, 24]. The Cochrane Rapid Review Methods Group has recently released interim methodological guidelines for undertaking rapid reviews [6], advising authors to describe where their protocol deviates from a systematic review and detail any biases that these deviations may introduce [18, $19,21]$. We have followed the Cochrane recommended methodology [6]. A rapid review reporting guideline is currently under development [25] and this review is therefore reported based on the PRISMA 2020 statement for systematic reviews, with justifications provided where our approach deviated [26].

Prospective review protocol registration on the PROSPERO database is the current gold standard, but, at the time of writing, PROSPERO does not accept records for rapid reviews [27]. The protocol was therefore not published in advance.

\section{Eligibility criteria}

The inclusion and exclusion criteria are summarised in Table 1. We used Strech et al.s Methodology, Issues, Participants (MIP) structure for our eligibility criteria, which is recommended for systematic reviews in 'empirical bioethics' [28]. The criteria reflect three assumptions. First, that the inclusion of 'ethical challenge(s)' in the title would increase the likelihood that this was the authors' preferred term for the concept under investigation, and therefore increase the probability of a definition being provided. Second, that studies aiming to describe empirical data and identify ethical challenges in real-world contexts are most likely to contain a definition to guide researchers in identifying these challenges as they collect and analyse data. Third, that structured reviews of studies of ethical challenges are likely to include a definition to allow researchers to reliably recognise an ethical challenge in retrieved records. We used a 5-year timeframe as a date restriction. This reflected a balance between adequately covering recent use of the term and time and resource restrictions of the rapid review.

\section{Information sources}

The search strategy was as follows:

'ethical challenge'ti OR 'ethical challenges.ti.

We searched Medline (Ovid interface), Philosopher's Index (OVID interface), EMBASE (OVID interface), and CINAHL (Cumulative Index to Nursing and Allied Health Literature, EBSCO interface) for studies indexed over a five-year period between April 2016 and April 2021. These resources cover the breadth of healthcare research. Including Philosopher's Index increased 
Table 1 Inclusion and exclusion criteria

\begin{tabular}{|c|c|c|}
\hline & Inclusion criteria & Exclusion criteria \\
\hline Types of participants & Any participants & No study will be excluded based on participant characteristics \\
\hline Issues & Studies examining 'ethical challenge(s)' in any healthcare context & Studies not reporting research in a healthcare context \\
\hline Methodologies & $\begin{array}{l}\text { Qualitative studies, mixed methods and quantitative studies, sys- } \\
\text { tematic reviews, structured but non-systemic reviews (narrative } \\
\text { syntheses, rapid reviews, scoping reviews and other records with } \\
\text { a described protocol that could be independently followed.) or } \\
\text { their published protocols }\end{array}$ & $\begin{array}{l}\text { These may include expert opinion, bioethical argument } \\
\text { pieces or case studies and analysis.Expert reviews on topics } \\
\text { with no formal structure or published protocol details }\end{array}$ \\
\hline Timeframe & $\begin{array}{l}\text { Five years. Publications indexed between 01/04/2016 and } \\
31 / 03 / 2021\end{array}$ & Indexed outside of this timeframe \\
\hline Type of publications & $\begin{array}{l}\text { Reports that contain the phrase 'ethical challenge }(s)^{\prime} \text { in the title } \\
\text { Peer-reviewed journal publications of empirical research or } \\
\text { structured reviews published in English }\end{array}$ & $\begin{array}{l}\text { Where no full text is available through the university subscrip- } \\
\text { tion, study authors will be contacted for full text. If there is no } \\
\text { response within two weeks, the study will be excluded } \\
\text { The following will also be excluded: } \\
\text { Conference abstracts } \\
\text { Editorials, letters, or comment/opinion pieces } \\
\text { Book sections }\end{array}$ \\
\hline
\end{tabular}

coverage of the bioethics literature. We did not search the grey literature [6]. The search strategy was tested by successfully retrieving three sentinel studies known to the research team.

\section{Study selection}

Retrieved studies were imported into Endnote X9.2 [29]. Records unavailable through institutional subscriptions were requested from corresponding authors. If unavailable 14 days after the request, the record was excluded. A random sample of $20 \%$ of records were dual screened at the title/abstract level by GS/MD. After discussion, the remainder were screened by GS. At full-text screening, a further $20 \%$ were dual screened by GS/MD and, again after discussion, the remaining studies were screened by GS.

\section{Data extraction and analysis}

Data extraction was undertaken using a pre-piloted form, with the first 5 records dually extracted by GS and MD. Data from the remaining included studies was then extracted by GS, with correctness and completeness checked by MD. We collected data on date of publication, authors, journal, country (for primary studies), methodology, definition of 'ethical challenge(s)' (present (yes/no)) and (where offered) the definition provided, and any closely related terms used, with counts of all terms used in each article. For closely related terms, data was extracted from the authors' text, but not from direct quotations from qualitative research. Where definitions of 'ethical challenge(s)' were offered and/or related terms were identified, these were categorised and counted following the principles of summative content analysis [30]. Summative content analysis combines both the quantitative counting of specific content or words/ terms with latent content analysis to identify and categorise their meanings. We identified keywords ('ethical challenge(s)' and closely related terms) deployed by the authors of the included papers, both prior to and during data analysis, and analysed the retrieved definitions. This approach allowed for exploration of both the content of definitions and development of insights into the use of related terms.

\section{Risk of bias assessment}

The focus of the rapid review was the definition of the term 'ethical challenge(s)' within retrieved records. We therefore did not undertake quality assessment for the included studies and reviews.

\section{Results}

831 records were retrieved, reduced to 393 after deduplication. 238 records were excluded after reviewing the title and/or abstract. 157 records were identified for full text screening, with 3 unavailable [31-33]. 82 records were excluded at full text stage and 72 records were included for analysis. See Fig. 1 for the PRISMA flowchart.

\section{Record characteristics}

Of the 72 included records, 53 were empirical studies [34-86], 10 non-systematic reviews [87-96], 7 systematic reviews [12-14, 97-100], 1 systematic review protocol [101], and 1 non-systematic review protocol [102]. Of the 53 empirical studies, 42 (79\%) were qualitative studies [34-36, 38-44, 47, 48, 50-52, 54-58, 60, $62-67,69,71-77,79-81,83-86], 6$ (12\%) used a mixed methods approach $[45,46,53,59,61,68]$, and $5(10 \%)$ 


\section{Identification of studies via databases and registers}
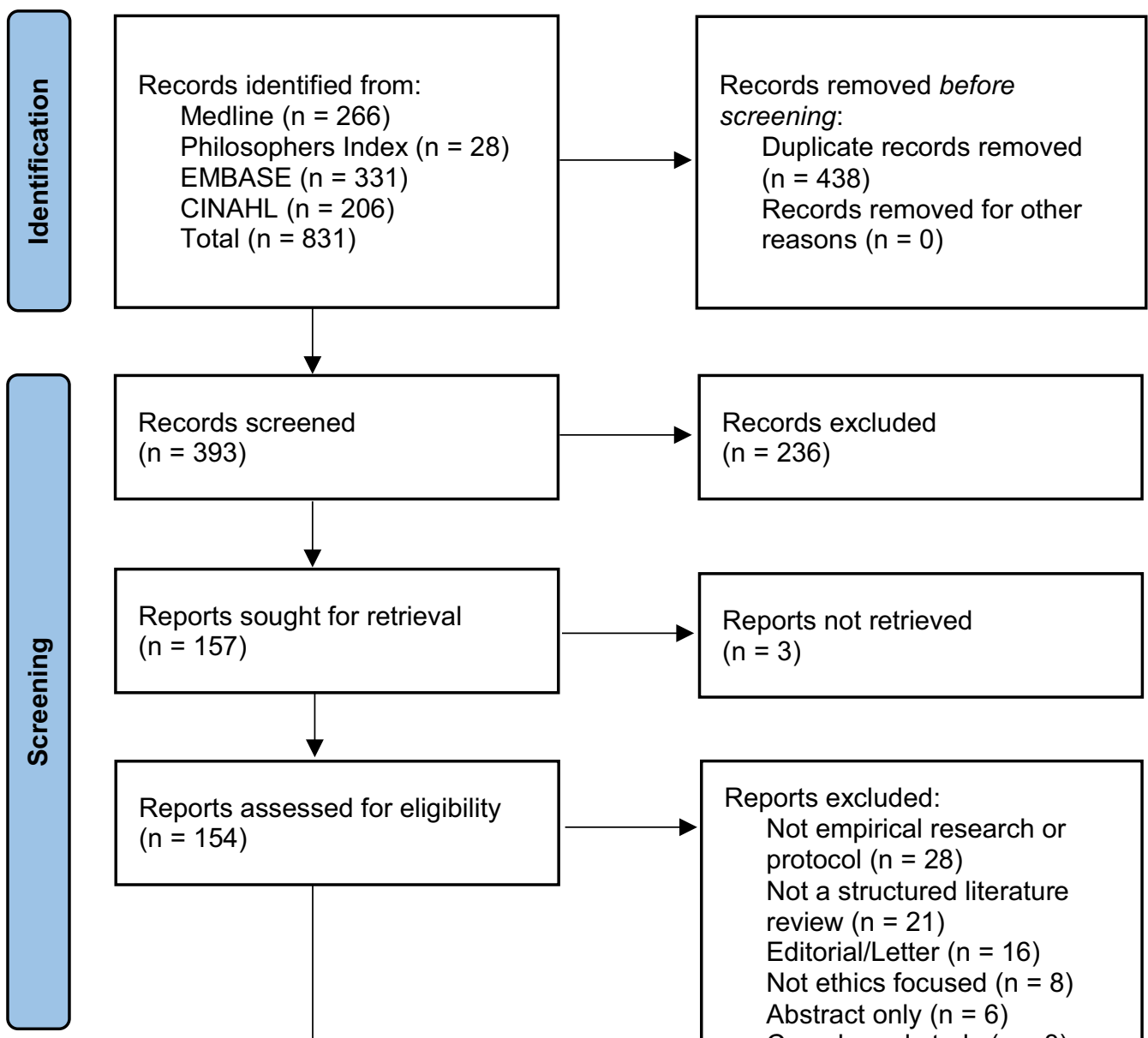

Records screened $(n=393)$
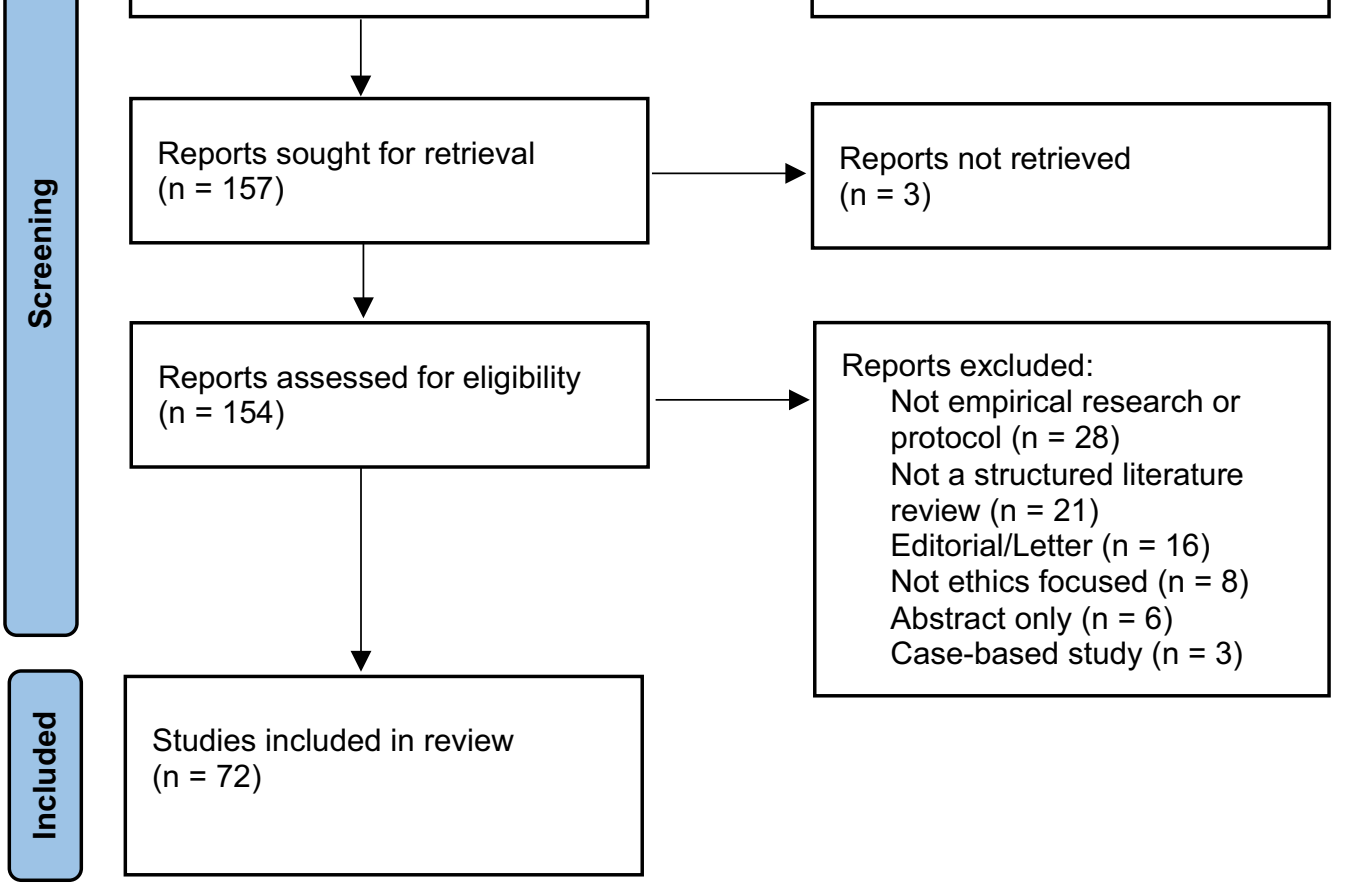

Studies included in review $(n=72)$

Fig. 1 PRISMA flow diagram of record identification

were quantitative $[37,49,70,78,82] .7 / 56$ empirical studies, all qualitative interview studies, recruited participants internationally with no specific location stated $[40,54,55,58,60,63,73]$. Of the remaining studies, all but one were single-country studies: Botswana [75], Canada [41, 65], China [57], Denmark [39, 43], Dominican Republic [44], Germany [51, 84], India [61], Iran $[38,46,49,68,70-72,78,82,98]$, Italy [45], Mexico [87], the Netherlands [76], New Zealand [47], Norway [42, 52, 56, 64, 80, 81, 83], Saudi Arabia [34-37], Tanzania [69, 74], Uganda [67], UK [86], and USA [50, $53,59,62,66,77,79,85,85]$. The remaining study was undertaken in both Sierra Leone and the UK [48]. See Table 2 for a summary.

\section{Findings}

$12 / 72(17 \%)$ of retrieved studies offered an explicit definition for 'ethical challenge(s)' [12-14, 48, 50, 56, 57, 66, $69,81,98,101]$. Definitions were more likely to be found in more recent publications, with $4 / 12$ included studies published in 2016-2018 [14, 48, 56, 81], and 8/12 published in 2019-2021 [12, 13, 50, 57, 66, 69, 98, 101]. The included study locations were evenly distributed, matching the overall pattern of retrieved studies, with 
Table 2 Included study details

\begin{tabular}{|c|c|c|c|c|c|}
\hline References & Title & Published & Country & Research Methodology & Definition \\
\hline Draper and Jenkins [48] & $\begin{array}{l}\text { Ethical challenges experienced } \\
\text { by UK military medical person- } \\
\text { nel deployed to Sierra Leone } \\
\text { (operation GRITROCK) during } \\
\text { the 2014-2015 Ebola outbreak: a } \\
\text { qualitative study }\end{array}$ & 2017 & UK/Sierra Leone & Qualitative & Y \\
\hline Forbes and Phillips [50] & $\begin{array}{l}\text { Ethical Challenges Encountered by } \\
\text { Clinical Trials Nurses: A Grounded } \\
\text { Theory Study }\end{array}$ & 2020 & USA & Qualitative & Y \\
\hline Hem et al. [14] & $\begin{array}{l}\text { Ethical challenges when using } \\
\text { coercion in mental healthcare: A } \\
\text { systematic literature review }\end{array}$ & 2018 & n/a review & Systematic Review & Y \\
\hline Heggestad et al. [13] & $\begin{array}{l}\text { Ethical challenges in home-based } \\
\text { care: A systematic literature review }\end{array}$ & 2020 & n/a review & Systematic Review & Y \\
\hline Jakobsen and Sørlie [56] & $\begin{array}{l}\text { Ethical challenges: Trust and leader- } \\
\text { ship in dementia care }\end{array}$ & 2016 & Norway & Qualitative & Y \\
\hline Jia et al. [57] & $\begin{array}{l}\text { Nurses' ethical challenges caring for } \\
\text { people with COVID-19: A qualita- } \\
\text { tive study }\end{array}$ & 2021 & China & Qualitative & Y \\
\hline Larkin et al. [66] & $\begin{array}{l}\text { Ethical challenges experienced by } \\
\text { clinical research nurses: A qualita- } \\
\text { tive study }\end{array}$ & 2019 & USA & Qualitative & Y \\
\hline Mlughu et al. [69] & $\begin{array}{l}\text { Voluntary HIV Counseling and } \\
\text { Testing Among Commercial } \\
\text { Motorcyclist Youths: An Exploration } \\
\text { of Ethical Challenges and Coping } \\
\text { Mechanisms in Dar es Salaam }\end{array}$ & 2020 & Tanzania & Qualitative & Y \\
\hline Saghafi et al. [98] & $\begin{array}{l}\text { Examining the ethical challenges in } \\
\text { managing elder abuse: a systematic } \\
\text { review }\end{array}$ & 2019 & n/a review & Systematic Review & Y \\
\hline Schofield et al. [101] & $\begin{array}{l}\text { Real-world ethics in palliative care: } \\
\text { protocol for a systematic review of } \\
\text { the ethical challenges reported by } \\
\text { specialist palliative care practition- } \\
\text { ers in their clinical practice }\end{array}$ & 2019 & $\mathrm{n} / \mathrm{a}$ review & Systematic Review protocol & Y \\
\hline Schofield et al. [12] & $\begin{array}{l}\text { Real-world ethics in palliative care: } \\
\text { A systematic review of the ethical } \\
\text { challenges reported by specialist } \\
\text { palliative care practitioners in their } \\
\text { clinical practice }\end{array}$ & 2021 & $\mathrm{n} / \mathrm{a}$ review & Systematic Review & Y \\
\hline Storaker et al. [81] & $\begin{array}{l}\text { From painful busyness to emo- } \\
\text { tional immunization: Nurses' experi- } \\
\text { ences of ethical challenges }\end{array}$ & 2017 & Norway & Qualitative & Y \\
\hline Alahmad et al. [34] & $\begin{array}{l}\text { Ethical challenges regarding the } \\
\text { use of stem cells: interviews with } \\
\text { researchers from Saudi Arabia }\end{array}$ & 2020 & Saudi Arabia & Qualitative & $\mathrm{N}$ \\
\hline Alahmad et al. [35] & $\begin{array}{l}\text { Ethical Challenges of Pediatric Can- } \\
\text { cer Care: Interviews With Nurses in } \\
\text { Saudi Arabia }\end{array}$ & 2020 & Saudi Arabia & Qualitative & $\mathrm{N}$ \\
\hline Alahmad et al. [37] & $\begin{array}{l}\text { Ethical challenges in consent } \\
\text { procedures involving pediatric } \\
\text { cancer patients in Saudi Arabia: An } \\
\text { exploratory survey }\end{array}$ & 2021 & Saudi Arabia & Qualitative & $\mathrm{N}$ \\
\hline Alahmad et al. [36] & $\begin{array}{l}\text { Ethical Challenges Related to the } \\
\text { Novel Coronavirus (COVID-19) Out- } \\
\text { break: Interviews With Professionals } \\
\text { From Saudi Arabia }\end{array}$ & 2021 & Saudi Arabia & Qualitative & $\mathrm{N}$ \\
\hline Ayala-Yáñez et al. [87] & $\begin{array}{l}\text { Violence against trainees: urgent } \\
\text { ethical challenges for medical } \\
\text { educators and academic leaders in } \\
\text { perinatal medicine }\end{array}$ & 2020 & n/a Review & Non-systematic Review & $\mathrm{N}$ \\
\hline
\end{tabular}


Table 2 (continued)

\begin{tabular}{|c|c|c|c|c|c|}
\hline References & Title & Published & Country & Research Methodology & Definition \\
\hline Bijani and Mohammadi [38] & $\begin{array}{l}\text { Ethical challenges of caring for } \\
\text { burn patients: a qualitative study }\end{array}$ & 2021 & Iran & Qualitative & N \\
\hline Binns et al. [88] & $\begin{array}{l}\text { Ethical Challenges in Infant Feeding } \\
\text { Research }\end{array}$ & 2017 & n/a Review & Non-systematic Review & N \\
\hline Bladt et al. [39] & $\begin{array}{l}\text { Empirical Investigation of Ethical } \\
\text { Challenges Related to the Use of } \\
\text { Biological Therapies }\end{array}$ & 2020 & Denmark & Qualitative & N \\
\hline Boulanger et al. [40] & $\begin{array}{l}\text { Developing and Implementing } \\
\text { new TB Technologies: Key Inform- } \\
\text { ants' Perspectives on the Ethical } \\
\text { Challenges }\end{array}$ & 2020 & International & Qualitative & N \\
\hline Bourbonnais et al. [41] & $\begin{array}{l}\text { Conditions and ethical challenges } \\
\text { that could influence the implemen- } \\
\text { tation of technologies in nursing } \\
\text { homes: A qualitative study }\end{array}$ & 2019 & Canada & Qualitative & N \\
\hline Brodtkorb et al. [42] & $\begin{array}{l}\text { Preserving dignity in end-of-life } \\
\text { nursing home care: Some ethical } \\
\text { challenges }\end{array}$ & 2017 & Norway & Qualitative & N \\
\hline Bruun et al. [43] & $\begin{array}{l}\text { Ethical challenges assessed in the } \\
\text { clinical ethics Committee of Psy- } \\
\text { chiatry in the region of Southern } \\
\text { Denmark in 2010-2015: a qualita- } \\
\text { tive content analyses }\end{array}$ & 2018 & Denmark & Qualitative & N \\
\hline Canario Guzmán et al. [44] & $\begin{array}{l}\text { Ethical challenges for international } \\
\text { collaborative research partnerships } \\
\text { in the context of the Zika outbreak } \\
\text { in the Dominican Republic: a quali- } \\
\text { tative case study }\end{array}$ & 2017 & Dominican Republic & Qualitative & N \\
\hline Carnevale et al. [45] & $\begin{array}{l}\text { Correctional nursing in Liguria, Italy: } \\
\text { examining the ethical challenges }\end{array}$ & 2018 & Italy & Mixed-methods & $\mathrm{N}$ \\
\hline Cartolovni and Habek [89] & $\begin{array}{l}\text { Guidelines for the management of } \\
\text { the social and ethical challenges in } \\
\text { brain death during pregnancy }\end{array}$ & 2019 & n/a review & Non-systematic Review & N \\
\hline Delpasand et al. [46] & $\begin{array}{l}\text { Ethical challenges in the relation- } \\
\text { ship between the pharmacist and } \\
\text { patient in Iran. International Journal } \\
\text { of Human Rights in Healthcare }\end{array}$ & 2020 & Iran & Mixed Methods & $\mathrm{N}$ \\
\hline Donnelly and Walker [47] & $\begin{array}{l}\text { Enabling first and second year doc- } \\
\text { tors to negotiate ethical challenges } \\
\text { in end-of-life care: a qualitative } \\
\text { study }\end{array}$ & 2021 & New Zealand & Qualitative & $\mathrm{N}$ \\
\hline Ebrahimi and Ebrahimi [49] & $\begin{array}{l}\text { Pediatric residents' and attending } \\
\text { physicians' perspectives on the } \\
\text { ethical challenges of end of life care } \\
\text { in children }\end{array}$ & 2018 & Iran & Quantitative & $\mathrm{N}$ \\
\hline Ewuoso et al. [100] & $\begin{array}{l}\text { How do healthcare profession- } \\
\text { als respond to ethical challenges } \\
\text { regarding information manage- } \\
\text { ment? A review of empirical studies }\end{array}$ & 2021 & n/a review & Systematic Review & $\mathrm{N}$ \\
\hline Forbes and Phillips [50] & $\begin{array}{l}\text { Ethical Challenges Encountered by } \\
\text { Clinical Trials Nurses: A Grounded } \\
\text { Theory Study }\end{array}$ & 2020 & USA & Qualitative & $\mathrm{N}$ \\
\hline Gagyor et al. [51] & $\begin{array}{l}\text { Ethical challenges in primary care: } \\
\text { a focus group study with general } \\
\text { practitioners, nurses and informal } \\
\text { caregivers }\end{array}$ & 2019 & Germany & Qualitative & $\mathrm{N}$ \\
\hline Haugom et al. [52] & $\begin{array}{l}\text { Ethical challenges of seclusion } \\
\text { in psychiatric inpatient wards: a } \\
\text { qualitative study of the experi- } \\
\text { ences of Norwegian mental health } \\
\text { professionals }\end{array}$ & 2019 & Norway & Qualitative & N \\
\hline
\end{tabular}


Table 2 (continued)

\begin{tabular}{|c|c|c|c|c|c|}
\hline References & Title & Published & Country & Research Methodology & Definition \\
\hline Hawking et al. [53] & $\begin{array}{l}\text { "Can virtue be taught?": a content } \\
\text { analysis of medical students' opin- } \\
\text { ions of the professional and ethical } \\
\text { challenges to their professional } \\
\text { identity formation }\end{array}$ & 2020 & USA & Mixed-methods & N \\
\hline Hofmann [90] & $\begin{array}{l}\text { Informing about mammographic } \\
\text { screening: Ethical challenges and } \\
\text { suggested solutions }\end{array}$ & 2020 & $\mathrm{n} / \mathrm{a}$ review & Non-systematic Review & $N$ \\
\hline Hunt et al. [91] & $\begin{array}{l}\text { Ethical Challenges in the Provision } \\
\text { of Mental Health Services for Chil- } \\
\text { dren and Families During Disasters }\end{array}$ & 2018 & $\mathrm{n} / \mathrm{a}$ review & Non-systematic Review & N \\
\hline Hyder and Krubiner [54] & $\begin{array}{l}\text { Ethical Challenges in Designing } \\
\text { and Implementing Health Systems } \\
\text { Research: Experiences from the } \\
\text { Field }\end{array}$ & 2016 & International & Qualitative & N \\
\hline Jackson et al. [55] & $\begin{array}{l}\text { Trust and the ethical challenges in } \\
\text { the use of whole genome sequenc- } \\
\text { ing for tuberculosis surveillance: } \\
\text { a qualitative study of stakeholder } \\
\text { perspectives }\end{array}$ & 2019 & International & Qualitative & $N$ \\
\hline Johnson and Parker [92] & $\begin{array}{l}\text { Ethical challenges in pathogen } \\
\text { sequencing: a systematic scoping } \\
\text { review }\end{array}$ & 2020 & n/a review & Non-systematic Review & $N$ \\
\hline Kalkman et al. [58] & $\begin{array}{l}\text { Stakeholders'views on the ethical } \\
\text { challenges of pragmatic trials inves- } \\
\text { tigating pharmaceutical drugs }\end{array}$ & 2016 & International & Qualitative & $N$ \\
\hline Kasper et al. [59] & $\begin{array}{l}\text { Perspectives and Solutions from } \\
\text { Clinical Trainees and Mentors } \\
\text { Regarding Ethical Challenges Dur- } \\
\text { ing Global Health Experiences }\end{array}$ & 2020 & USA & Mixed-methods & N \\
\hline Kelley et al. [60] & $\begin{array}{l}\text { Ethical challenges in research with } \\
\text { orphans and vulnerable children: } \\
\text { A qualitative study of researcher } \\
\text { experiences }\end{array}$ & 2016 & International & Qualitative & N \\
\hline Kemparaj et al. [61] & $\begin{array}{l}\text { The Top } 10 \text { Ethical Challenges in } \\
\text { Dental Practice in Indian Scenario }\end{array}$ & 2015 & India & Mixed-methods & N \\
\hline Klitzman [62] & $\begin{array}{l}\text { Unconventional combinations of } \\
\text { prospective parents: ethical chal- } \\
\text { lenges faced by IVF providers }\end{array}$ & 2017 & USA & Qualitative & $N$ \\
\hline Komparic et al. [63] & $\begin{array}{l}\text { A failure in solidarity: Ethical chal- } \\
\text { lenges in the development and } \\
\text { implementation of new tuberculo- } \\
\text { sis technologies }\end{array}$ & 2019 & International & Qualitative & $N$ \\
\hline Laholt et al. [64] & $\begin{array}{l}\text { Ethical challenges experienced by } \\
\text { public health nurses related to ado- } \\
\text { lescents' use of visual technologies }\end{array}$ & 2019 & Norway & Qualitative & $N$ \\
\hline Laliberte et al. [65] & $\begin{array}{l}\text { Ethical Challenges for Patient } \\
\text { Access to Physical Therapy: Views } \\
\text { of Staff Members from Three } \\
\text { Publicly-Funded Outpatient Physi- } \\
\text { cal Therapy Departments }\end{array}$ & 2017 & Canada & Qualitative & $N$ \\
\hline Larkin et al.[66] & $\begin{array}{l}\text { Ethical challenges experienced by } \\
\text { clinical research nurses:: A qualita- } \\
\text { tive study }\end{array}$ & 2019 & USA & Qualitative & N \\
\hline MacDonald and Shemie [93] & $\begin{array}{l}\text { Ethical Challenges and the Dona- } \\
\text { tion Physician Specialist: A Scoping } \\
\text { Review }\end{array}$ & 2017 & n/a review & Scoping Review & $N$ \\
\hline $\begin{array}{l}\text { Martins Pereira and Hernandez- } \\
\text { Marrero [97] }\end{array}$ & $\begin{array}{l}\text { Ethical challenges of outcome } \\
\text { measurement in palliative care } \\
\text { clinical practice: a systematic } \\
\text { review of systematic reviews }\end{array}$ & 2018 & n/a review & Systematic Review & $N$ \\
\hline
\end{tabular}


Table 2 (continued)

\begin{tabular}{|c|c|c|c|c|c|}
\hline References & Title & Published & Country & Research Methodology & Definition \\
\hline Mbalinda et al. [67] & $\begin{array}{l}\text { Ethical challenges of the healthcare } \\
\text { transition to adult antiretroviral } \\
\text { therapy (ART) clinics for adoles- } \\
\text { cents and young people with HIV } \\
\text { in Uganda }\end{array}$ & 2021 & Uganda & Qualitative & N \\
\hline Mehdipour Rabori et al. [68] & $\begin{array}{l}\text { Nursing students' ethical challenges } \\
\text { in the clinical settings: A mixed- } \\
\text { methods study }\end{array}$ & 2019 & Iran & Mixed-methods & N \\
\hline Moeini et al. [70] & $\begin{array}{l}\text { Ethical challenges of obtaining } \\
\text { informed consent from surgical } \\
\text { patients }\end{array}$ & 2020 & Iran & Quantitative & N \\
\hline Morley et al. [86] & $\begin{array}{l}\text { Moral Distress and Austerity: An } \\
\text { Avoidable Ethical Challenge in } \\
\text { Healthcare }\end{array}$ & 2019 & UK & Qualitative & N \\
\hline Naseri-Salahshour and Sajadi [71] & $\begin{array}{l}\text { Ethical challenges of novice nurses } \\
\text { in clinical practice: Iranian perspec- } \\
\text { tive }\end{array}$ & 2020 & Iran & Qualitative & N \\
\hline Naseri-Salahshour and Sajadi [72] & $\begin{array}{l}\text { From Suffering to Indifference: } \\
\text { Reaction of Novice Nurses to } \\
\text { Ethical Challenges in First Year of } \\
\text { Clinical Practice }\end{array}$ & 2019 & Iran & Qualitative & N \\
\hline Nicholls et al. [73] & $\begin{array}{l}\text { The ethical challenges raised in the } \\
\text { design and conduct of pragmatic } \\
\text { trials: An interview study with key } \\
\text { stakeholders }\end{array}$ & 2019 & International & Qualitative & N \\
\hline Pancras et al. [74] & $\begin{array}{l}\text { Non-medical facilitators and bar- } \\
\text { riers towards accessing haemodi- } \\
\text { alysis services: an exploration of } \\
\text { ethical challenges }\end{array}$ & 2018 & Tanzania & Qualitative & N \\
\hline Sabone et al. [75] & $\begin{array}{l}\text { Everyday ethical challenges of } \\
\text { nurse-physician collaboration }\end{array}$ & 2020 & Botswana & Qualitative & N \\
\hline Saigle and Racine [94] & $\begin{array}{l}\text { Ethical challenges faced by health- } \\
\text { care professionals who care for } \\
\text { suicidal patients: a scoping review }\end{array}$ & 2018 & $\mathrm{n} / \mathrm{a}$ review & Non-systematic Review & N \\
\hline Saigle et al. [95] & $\begin{array}{l}\text { Identifying Gaps in Suicide } \\
\text { Research: A Scoping Review of } \\
\text { Ethical Challenges and Proposed } \\
\text { Recommendations }\end{array}$ & 2017 & n/a review & Non-systematic review & N \\
\hline Seekles et al. [76] & $\begin{array}{l}\text { Inspectors'Ethical Challenges in } \\
\text { Health Care Regulation: A Pilot } \\
\text { Study }\end{array}$ & 2017 & Netherlands & Qualitative & N \\
\hline Segal et al. [77] & $\begin{array}{l}\text { County Jail or Psychiatric Hospital? } \\
\text { Ethical Challenges in Correctional } \\
\text { Mental Health Care }\end{array}$ & 2018 & USA & Qualitative & $\mathrm{N}$ \\
\hline Shayestefar et al. [78] & $\begin{array}{l}\text { Ethical challenges in pediatrics } \\
\text { from the viewpoints of Iranian } \\
\text { pediatric residents }\end{array}$ & 2018 & Iran & Quantitative & N \\
\hline Sinow et al. [79] & $\begin{array}{l}\text { How Anesthesiologists Experience } \\
\text { and Negotiate Ethical Challenges } \\
\text { from Drug Shortages }\end{array}$ & 2020 & USA & Qualitative & N \\
\hline Slettebo et al. [80] & $\begin{array}{l}\text { Conflicting rationales: leader's } \\
\text { experienced ethical challenges in } \\
\text { community health care for older } \\
\text { people }\end{array}$ & 2018 & Norway & Qualitative & N \\
\hline Solvoll et al. [117] & $\begin{array}{l}\text { Ethical challenges in everyday work } \\
\text { with adults with learning disabilities }\end{array}$ & 2015 & Norway & Qualitative & $N$ \\
\hline Sun et al. [102] & $\begin{array}{l}\text { Ethical challenges related to assis- } \\
\text { tive product access for older adults } \\
\text { and adults living with a disability: a } \\
\text { scoping review protocol }\end{array}$ & 2017 & n/a review & Scoping Review Protocol & $N$ \\
\hline
\end{tabular}


Table 2 (continued)

\begin{tabular}{|c|c|c|c|c|c|}
\hline References & Title & Published & Country & Research Methodology & Definition \\
\hline Taebi et al. [82] & $\begin{array}{l}\text { Ethical Challenges of Embryo } \\
\text { Donation in Embryo Donors and } \\
\text { Recipients }\end{array}$ & 2018 & Iran & Quantitative & $\mathrm{N}$ \\
\hline Tonnessen et al. [83] & $\begin{array}{l}\text { Ethical challenges related to next of } \\
\text { kin—nursing staffs' perspective }\end{array}$ & 2016 & Norway & Qualitative & $\mathrm{N}$ \\
\hline Ullrich et al. [84] & $\begin{array}{l}\text { Ethical challenges in family caregiv- } \\
\text { ers of patients with advanced } \\
\text { cancer-a qualitative study }\end{array}$ & 2020 & Germany & Qualitative & $\mathrm{N}$ \\
\hline Verma et al. [85] & $\begin{array}{l}\text { Ethical Challenges in Caring for } \\
\text { Unrepresented Adults: A Qualitative } \\
\text { Study of Key Stakeholders }\end{array}$ & 2019 & USA & Qualitative & $\mathrm{N}$ \\
\hline West et al. [99] & $\begin{array}{l}\text { Operationalising ethical challenges } \\
\text { in dementia research-a systematic } \\
\text { review of current evidence }\end{array}$ & 2017 & n/a review & Systematic review & $\mathrm{N}$ \\
\hline Wilson et al. [96] & $\begin{array}{l}\text { Ethical Challenges in Community- } \\
\text { Based Participatory Research: A } \\
\text { Scoping Review }\end{array}$ & 2017 & n/a review & Non-systematic Review & N \\
\hline
\end{tabular}

studies from high- $[48,50,56,66,81]$, middle- $[57,98]$, and low-income settings $[48,69]$. The identified studies included eight qualitative studies $[48,50,56,57,66$, $69,81,98], 3$ systematic reviews [12-14], and 1 systematic review protocol [101]. Two of these records were the systematic review protocol and the report from our group, which accordingly contained the same definition [12, 101], leaving 11 unique definitions. Definitions of 'ethical challenge(s)' identified in included studies are provided in Table 3. Additionally, 68/72 (94\%) reports used closely related terms synonymously in place of 'ethical challenge(s)' throughout their manuscript text, with between 1 and 8 different terms used within each report, and 32 different terms were identified. This occurred in both those reports that contained a definition and those that did not. See Table 4 for terms and frequencies.

Those records that offered explicit definitions used four approaches: (1) definition through concepts [12, 57, 66]; (2) reference to moral conflict, moral uncertainty or difficult choices [13, 14, 48, 57, 69, 98]; (3) definition by study participants [12, 48, 50, 56]; or (4) challenges as linked to their ability to generate emotional or moral distress within healthcare practitioners [14, 14, 66, 81]. Each definition was associated with one or more of the identified elements, although none covered all four approaches. We describe these approaches below.

\section{Approach 1: definition through concepts}

This approach involves primarily defining 'ethical challenge(s)' in terms of related concepts. All three definitions using this approach defined 'ethical challenge(s)' as a summative collection of related concepts, including 'ethical dilemmas', 'moral dilemmas', 'moral challenges', 'ethical issues', and 'ethical conflicts' $[12,57,66]$, for example:

'The expression "ethical challenges" mainly refers to ethical dilemmas and ethical conflicts as well as other scenarios where difficult choices have to be made' [57] p34

Only one went on to define the other concepts they utilised, 'ethical dilemmas' and 'ethical conflicts':

'Ethical dilemmas are described as situations that cannot be solved; decisions made between two options may be morally plausible but are equally problematic due to the circumstances. Ethical conflicts, on the contrary, arise when one is aware of the necessity of proper actions but he or she may have trouble exercising these actions because of certain internal or external factors.' [57] p34.

\section{Approach 2: moral conflict, moral uncertainty or difficult choices}

This approach anchors an ethical challenge to the requirement for an agent to make a (difficult) choice in a situation where moral principles conflict, or there is moral uncertainty as to the 'right' way forward.

'In this context, ethical challenge refers to the situation whereby every alternative is morally wrong and still one has to make a choice' [69] p676 'An ethical challenge occurs when one does not know how to behave and act in the best way...' [14] p93 


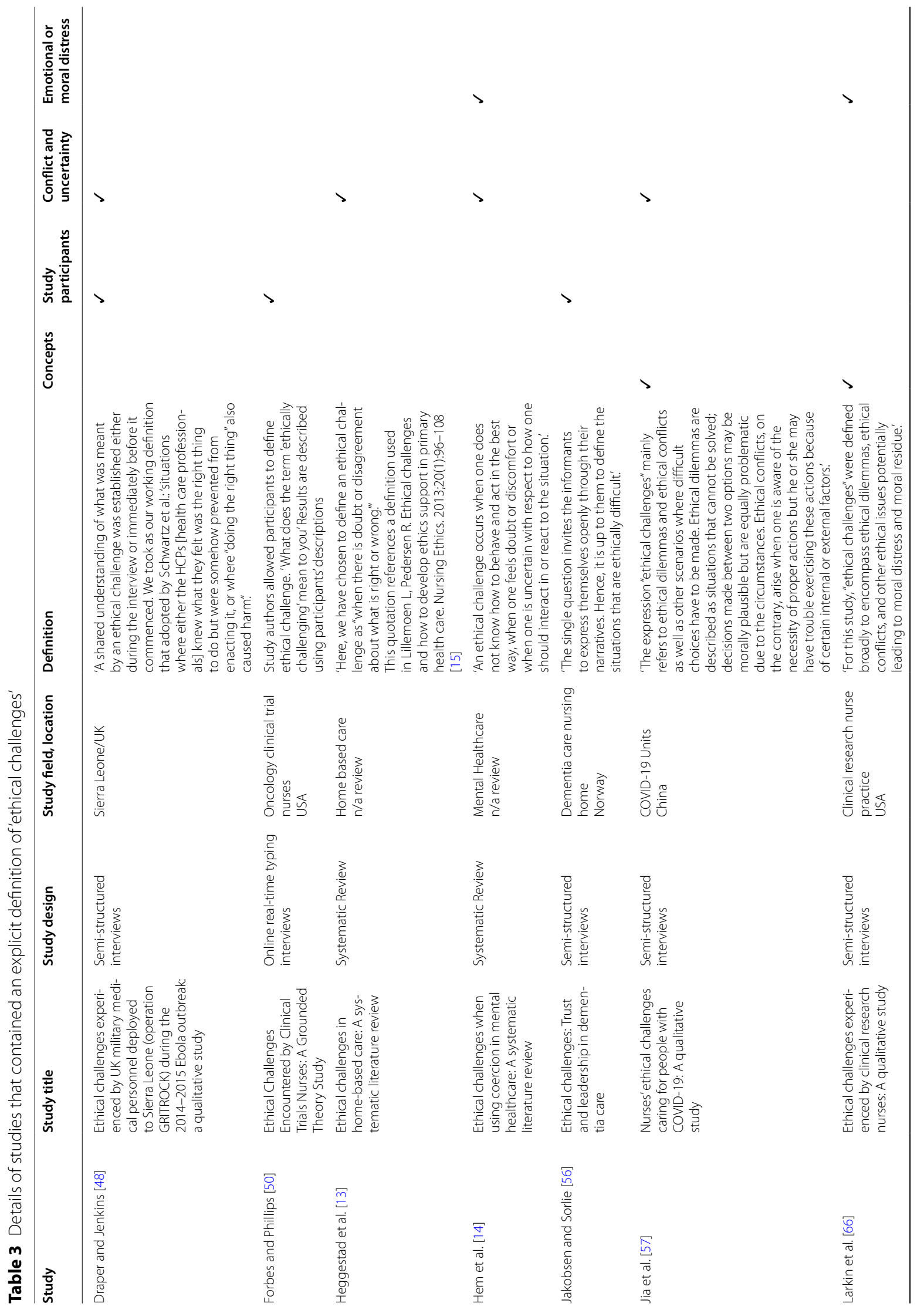




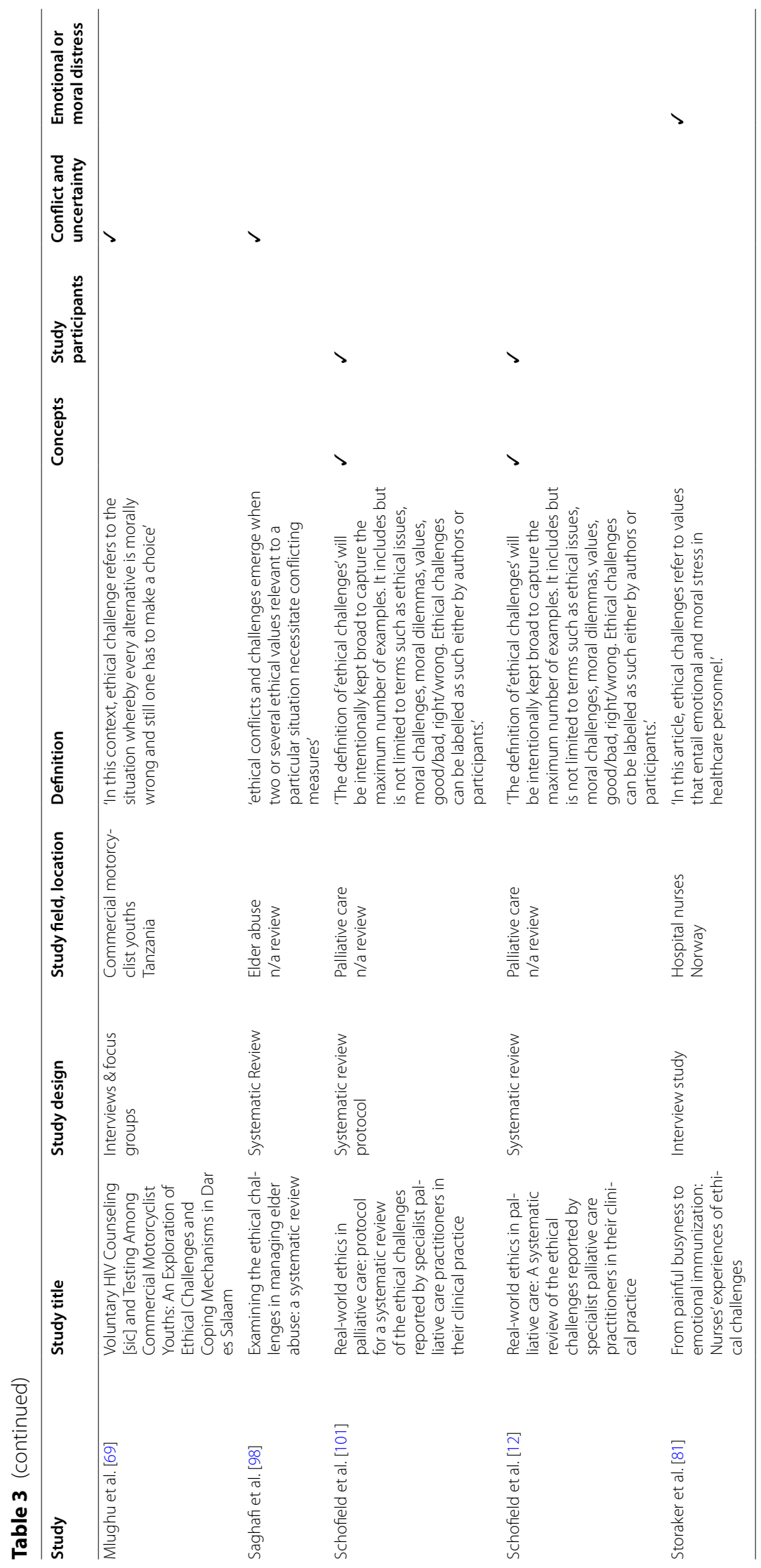




\section{Approach 3: definition by study participants}

Four of the definitions involved research participants themselves defining something as an 'ethical challenge' $[12,48,50,56]$, with three studies explicitly stating that participants would lead this definitional work [48, 50, 56]. Draper \& Jenkins offer a starting definition, adopted from Schwartz et al. [103] with which to prime participants, while Forbes and Phillips [50] and Jakobsen and Sørlie [56] left the definition fully with their participants (Table 3). Finally, Schofield et al. proposed a very broad definition (Table 3), alongside the specific statement that either participants or researchers could nominate something as an 'ethical challenge' [12].

\section{Approach 4: emotional or moral distress}

This final approach was to tie ethical challenges to situations where participants feel 'discomfort', emotional distress or more specifically moral distress or moral residue $[14,66,81]$. Larkin et al. are clear that this distress must be tied to moral causes, but Hem et al. and Storaker et al. also refer more broadly to 'discomfort' [14] and 'emotional stress' [81] respectively. For example:

In this article, ethical challenges refer to values that entail emotional and moral stress in healthcare personnel.' [81] p557

\section{Discussion}

To the authors' knowledge, this is the first rapid review to examine the use of the term 'ethical challenge(s)' in empirical healthcare research literature. Notably, only $12 / 72(17 \%)$ of included studies published in the last 5 years contained a definition for 'ethical challenge(s)', despite this being the focus of the research being reported. The definitions identified were found in qualitative studies and systematic reviews and were evenly distributed geographically across high-, middle- and lowincome settings. Definitions contained one or more of the identified approaches, although none contained elements from all four. Taken together, these findings suggest that a clear definition of 'ethical challenge(s)', and consistent use thereof, is currently lacking.

The four approaches indicate the diverse approaches to understanding 'ethical challenge(s)'. Approaches 1 and 2 explore the concept from opposite viewpoints, with approach 1 looking from the conceptual perspective, through terms such as 'dilemmas' and 'conflict', and approach 2 from a participant perspective, specifically in those situations in which someone is trying to make a decision in circumstances where the preferred option is not possible or when they perceive there to be clash in values they feel are important. Within the concept-led definitions (approach 1), the use of a plurality of terms highlights a potential risk of bias, as different readers may interpret these differently. For example, some terms, such as 'moral dilemma', have relatively well understood specific meanings for some readers, particularly those with philosophical training [104-106]. The presence in the literature of specific and multiple meanings for some related terms highlights the importance of empirical studies providing a definition of these additional terms alongside their primary definition for 'ethical challenge(s)'. This is more likely to be relevant where an a priori definition is used, but may be relevant to any prompting text for studies using a participant-led process, as in the study by Draper and Jenkins [48]. This clarity is important for both readers and future researchers who may undertake a secondary analysis of the data.

Approach 3 involves facilitating participants to nominate something as an ethical challenge [12, 48, 50, 56]. This speaks to an important question about who, in a research context, is permitted to define or describe the object of interest, in this case 'ethical challenge(s)'. Restricting the identification of 'ethical challenge(s)' to researchers alone may introduce bias by excluding input from those without bioethical 'expertise', but with important lived experience of the context under investigation. There is evidence that although clinicians can be sensitive to major ethical dilemmas, they can be less sensitive to small everyday ethical elements in clinical practice, and that ethical awareness varies between individuals [107, 108]. Additionally, there is evidence in healthcare ethics research that patients and carers identify ethical challenges in situations that healthcare workers do not [109]. Therefore, relying entirely on a particular stakeholders' perspectives (such as clinicians') may risk missing important ethical challenges present in a scenario (assuming, of course, that we can settle what counts as an 'ethical challenge(s)').

In Approach 4, ethical challenges were linked to situations in which participants felt discomfort [14], emotional stress [81], moral distress or moral residue [66]. These concepts are themselves defined in quite varied ways (see, for example, definitions of 'moral distress' in a systematic review by Morley et al. [110]), potentially leading to additional conceptual confusion. Identifying triggers for moral distress is important, as high levels of moral distress are known to have negative impacts on work environments and lead to increased levels of compassion fatigue, increased staff turnover rates and poorer patient outcomes [110-112]. However, it is also possible that the requirement that, to be identified as an ethical challenge, the situation must invoke stress or distress might result in the under-identification of ethical challenges. We anticipate that many practitioners will daily manage multiple low-level ethical challenges, 
Table 4 Use of terms closely related to 'ethical challenge'

\begin{tabular}{ll}
\hline $\begin{array}{l}\text { Number of studies containing the term } \\
\text { (total=75) }\end{array}$ & Term \\
\hline$>30$ & Ethical issues \\
$20-30$ & Ethical concerns \\
& Ethical dilemmas \\
& Ethical aspects \\
& Ethical conflicts \\
& Ethical considerations \\
& Ethical problems \\
& Ethically challenging/ \\
& demanding/difficult \\
& situations \\
& Ethical difficulties \\
& Moral challenges \\
& Ethical dimensions \\
& Ethical questions \\
& Ethical tensions \\
& Moral dilemmas \\
& Ethical complications \\
& Ethical components \\
$3-5$ & Ethical difficulties \\
& Ethical discussions \\
& Ethical disquiet \\
& Ethical elements \\
& Ethical factors \\
Ethical obstacles & Ethical struggles \\
& Ethical uncertainties \\
& Moral conflict \\
& Moral courage \\
& Moral considerations \\
& Moral issues \\
& Moral problems \\
& Moral question \\
& Morally relevant topics \\
& Moral situations \\
& \\
& \\
& \\
&
\end{tabular}

many of which will not generate moral distress or leave a moral residue. As such, the presence of moral distress may not be sufficient or even necessary in order to label a moral event an 'ethical challenge'. However, the relationship between 'ethical challenge(s)' and moral distress is complex, and some might argue that the latter has an important relationship to the former. For example, moral distress, as conceived by Jameton and others [110, 113, 114], is linked to the after-effects of having to handle ethical challenge(s), so some researchers might view the generation of moral distress as relevant to identifying ethical challenges.

Although our review revealed these four approaches, the wider literature indicates there may be alternative approaches available. For example, other potential approaches would define ethical challenges as events that interact with moral principles, such as autonomy, beneficence, non-maleficence or justice, as proposed by Beauchamp and Childress [115], or as events in which those principles clash, for example as used by Klingler et al. in their research focusing on ethical issues in health surveillance [116]. However, these approaches were not seen amongst our included papers.

Returning to our included papers, the high rates of use of closely related terms within included manuscript texts may add to difficulties in understanding the exact object of interest if these terms are being used as synonyms for 'ethical challenge(s)'. This may be particularly the case if terms used include those such as 'moral dilemma', which (as shown above) will have specific meanings for some readers. Interchangeable, undefined usage of these terms by study authors within study texts risks further exacerbating the problems caused by a lack of definitional clarity.

\section{Strengths and limitations}

This rapid review is the first systematic attempt to describe the definitions of 'ethical challenge(s)' available within the recent published literature.

There are, however, five limitations to note. First, the review only includes results from the past 5 years, which inevitably means that older publications, which may have contained further definitions of 'ethical challenge(s)', were excluded. The focus on the previous 5 years does, however, allow for an assessment of the term's use(s) within a reasonable period of time and was felt to be appropriate given the aims and resources available to this project.

Second, our three assumptions listed in the methodology section may have excluded some records that contained a relevant definition. However, these assumptions, and the resulting focus on two search terms, allowed for a balance between retrieved record numbers and team resources.

Third, the four databases searched were chosen for their focus on the healthcare ethics literature; we may therefore may have missed relevant usage in other fields or disciplines. Similarly, we did not search the grey literature, which might have excluded relevant research.

Fourth, for resource reasons, the assessment as to whether a related term was being used interchangeably in the text was undertaken by a single researcher (GS). This subjective assessment risks miscalculating both the number of interchangeable terms identified and the frequency counts.

Finally, we did not review the theoretical literature for conceptual definitions of 'ethical challenge(s)', hence the definitions we identified might not match completely conceptual understandings of the term. However, our review shows how the term is currently being used in the research literature. Indeed, if there are strong conceptual definitions within the theoretical literature, then it is clear that they are currently not reaching the researchers whose work was identified by our review. 


\section{Conclusions}

This review is the first, to our knowledge, to identify and describe definitions (and uses) of the widely-utilised concept of 'ethical challenge(s)' within healthcare research. Only $17 \%(12 / 72)$ of retrieved papers presented an explicit definition of 'ethical challenge(s)' before beginning to investigate this concept in context. The definitions found contained one or more of four identified approaches, with significant cross-reference to related terms and concepts which themselves have variation in their accepted meanings. We recommend that researchers define the phenomenon of interest-in this case, 'ethical challenge(s)' - to help ensure clarity. This should either be a priori, or, if using an approach that includes participant participation in the generation of the definition, reporting their final working definition a posteriori. The choice of definition should be justified, including the decision as to whether to include participants in this process. Additionally, if a definition references other conceptual terms, then consideration should be given to defining these as well.

The results of this rapid review suggest that a common conceptual understanding of the term 'ethical challenge(s)' is lacking within empirical bioethical research and that there is a need for researchers in this area to consider what conceptual formulations might be most useful. Again, failure to use definitions of crucial research concepts within empirical bioethics research potentially generates confusion and avoidable bias within research outputs, risking misleading ethical analyses, evaluations, and resulting recommendations. We therefore hope this review will help stimulate debate amongst empirical bioethics researchers on possible definitional content for such a commonly used term and prompt further discussion and research. Additionally, given the central role of patient and public partnership and involvement in research, further thought should be given to who should be involved in nominating something as a challenge worthy of study.

Following on from this work, there would be value in conducting an empirical bioethical project combining a full systematic review of definitions of 'ethical challenge(s)' (and related terms) integrated with an exploration of the conceptual literature to generate recommendations for approaches towards the content of potential definitions, perhaps related to the identified approaches above. Such a project could also ask authors who currently use the term 'ethical challenge(s)' in their research how they conceptualise this. Furthermore, work to better understand the benefits of including study participants in the definition process is also important. Finally, whilst researchers should justify whatever approach they choose to take, there may be merit in examining whether anything is lost if studies lack a robust or agreed definition, or whether doing so affords a flexibility and openness that allows for a broader range of ethical challenges to be identified.

\section{Acknowledgements \\ Not applicable.}

\section{Authors' contributions}

GS, MD and RH conceived of the idea for the review; LES, GS, MD and RH designed the review protocol; GS and MD conducted the literature searching, screening, data extraction and led on data interpretation but all authors were involved; GS led on drafting the manuscript; all authors critically revised the manuscript for content and approved the version to be published. All authors read and approved the final manuscript.

\section{Funding}

GS is supported by a Wellcome Trust Research Award for Health Professionals (208129/Z/17/Z). LES is funded by a Career Development Fellowship from the National Institute for Health Research. RH is part-funded by the Wellcome Trust (209841/Z/17/Z) and the NIHR Biomedical Research Centre at University Hospitals Bristol NHS Foundation Trust and the University of Bristol. He serves on various local, regional, and national ethics committees and related groups. The views expressed in this publication are those of the authors and not necessarily those of the NHS, the National Institute for Health Research, the Department of Health, or any of the other organisations with and for whom the authors work.

Availability of data and materials

All data is presented in this manuscript.

\section{Declarations}

Ethics approval and consent to participate

Not applicable.

\section{Consent for publication}

Not applicable.

\section{Competing interests}

The authors declare that there are no conflicts of interests.

\section{Author details}

${ }^{1}$ Centre for Ethics in Medicine, Population Health Sciences, Bristol Medical School, University of Bristol, Bristol BS8 2PS, UK. ${ }^{2}$ Paediatric Bioethics Centre, Great Ormond Street Hospital, London WC1N 3JH, UK. ${ }^{3}$ Palliative and End of Life Care Research Group, Population Health Sciences, Bristol Medical School, University of Bristol, Bristol BS8 2PS, UK.

Received: 10 June 2021 Accepted: 3 September 2021

Published online: 29 September 2021

\footnotetext{
References

1. Critical Appraisal Skills Programme. CASP Qualitative Checklist. 2018. https://casp-uk.net/wp-content/uploads/2018/01/CASP-QualitativeChecklist.pdf. Accessed 16 Aug 2018.

2. Consolidated criteria for reporting qualitative research (COREQ): a 32-item checklist for interviews and focus groups | The EQUATOR Network. https://www.equator-network.org/reporting-guidelines/coreq/. Accessed 2 Apr 2020.

3. Standards for reporting qualitative research: a synthesis of recommendations |The EQUATOR Network. https://www.equator-network.org/ reporting-guidelines/srar/. Accessed 2 Apr 2020.

4. Lewin S, Booth A, Glenton C, Munthe-Kaas H, Rashidian A, Wainwright $M$, et al. Applying GRADE-CERQual to qualitative evidence synthesis findings: introduction to the series. Implement Sci. 2018;13:2.
} 
5. The EQUATOR Network | Enhancing the QUAlity and Transparency of Health Research. https://www.equator-network.org/. Accessed 2 Apr 2020

6. Garritty C, Gartlehner G, Nussbaumer-Streit B, King VJ, Hamel C, Kamel C, et al. Cochrane Rapid Reviews Methods Group offers evidenceinformed guidance to conduct rapid reviews. J Clin Epidemiol. 2021;130:13-22.

7. Singh I. Evidence, epistemology and empirical bioethics. In: Cribb A, Ives J, Dunn M, editors. Empirical bioethics: theoretical and practical perspectives. Cambridge: Cambridge University Press; 2016. p. 67-83. https://doi.org/10.1017/9781139939829.006.

8. Ives J, Dunn M, Molewijk B, Schildmann J, Bærøe K, Frith L, et al. Standards of practice in empirical bioethics research: towards a consensus. BMC Med Ethics. 2018;19:68.

9. Mertz M, Inthorn J, Renz G, Rothenberger LG, Salloch S, Schildmann J, et al. Research across the disciplines: a road map for quality criteria in empirical ethics research. BMC Med Ethics. 2014;15:17.

10. Moher D, Shamseer L, Clarke M, Ghersi D, Liberati A, Petticrew M, et al. Preferred reporting items for systematic review and meta-analysis protocols (PRISMA-P) 2015 statement. Syst Rev. 2015:4:1.

11. Cronin P, Ryan F, Coughlan M. Concept analysis in healthcare research. Int J Ther Rehabil. 2010;17:62-8.

12. Schofield G, Dittborn M, Huxtable R, Brangan E, Selman LE. Real-world ethics in palliative care: a systematic review of the ethical challenges reported by specialist palliative care practitioners in their clinical practice. Palliat Med. 2021;35:315-34.

13. Heggestad AKT, Magelssen M, Pedersen R, Gjerberg E. Ethical challenges in home-based care: a systematic literature review. Nurs Ethics. 2020;28:628-44

14. Hem MH, Gjerberg E, Husum TL, Pedersen R. Ethical challenges when using coercion in mental healthcare: a systematic literature review. Nurs Ethics. 2018;25:92-110.

15. Lillemoen L, Pedersen R. Ethical challenges and how to develop ethics support in primary health care. Nurs Ethics. 2013;20:96-108.

16. Saarni SI, Halila R, Palmu P, Vänskä J. Ethically problematic treatment decisions in different medical specialties. J Med Ethics. 2008;34:262-7.

17. Self $D$, Skeel J, Jecker N. A comparison of the moral reasoning of physicians and clinical medical ethicists. Acad Med. 1993;68:852-5.

18. Ganann R, Ciliska D, Thomas H. Expediting systematic reviews: methods and implications of rapid reviews. Implement Sci IS. 2010;5:56.

19. Cameron A. Rapid versus full systematic reviews: an inventory of current mathods and practice in health technology assessment. Stepney: Royal Australasian College of Dental Surgeons; 2007.

20. Tricco AC, Antony J, Zarin W, Strifler L, Ghassemi M, Ivory J, et al. A scoping review of rapid review methods. BMC Med. 2015;13:224.

21. Haby MM, Chapman E, Clark R, Barreto J, Reveiz L, Lavis JN. What are the best methodologies for rapid reviews of the research evidence for evidence-informed decision making in health policy and practice: a rapid review. Health Res Policy Syst. 2016;14:83.

22. Gough D, Thomas J, Oliver S. Clarifying differences between review designs and methods. Syst Rev. 2012;1:28.

23. Watt A, Cameron A, Sturm L, Lathlean T, Babidge W, Blamey S, et al. Rapid reviews versus full systematic reviews: an inventory of current methods and practice in health technology assessment. Int J Technol Assess Health Care. 2008:24:133-9.

24. Khangura S, Konnyu K, Cushman R, Grimshaw J, Moher D. Evidence summaries: the evolution of a rapid review approach. Syst Rev. 2012;1:10.

25. Stevens A, Garritty C, Hersi M, Moher D. Developing PRISMA-RR, a reporting guideline for rapid reviews of primary studies (Protocol) 2018. https://www.equator-network.org/wp-content/uploads/2018/ 02/PRISMA-RRprotocol.pdf. Accessed 6 Oct 2019.

26. Page MJ, McKenzie JE, Bossuyt PM, Boutron I, Hoffmann TC, Mulrow CD, et al. The PRISMA 2020 statement: an updated guideline for reporting systematic reviews. BMJ. 2021;372:n71.

27. PROSPERO: International prospective register of systematic reviews. https://www.crd.york.ac.uk/prospero/. Accessed 10 June 2021.

28. Strech D, Synofzik M, Marckmann G. Systematic reviews of empirical bioethics. J Med Ethics. 2008;34:472-7.

29. The Endnote Team. Endnote X9.2. Philadelphia, PA: Clarivate Analysis; 2013
30. Hsieh H-F, Shannon SE. Three approaches to qualitative content analysis. Qual Health Res. 2005;15:1277-88.

31. Khalili M. Iranian nurses' ethical challenges in controlling children's fever. Int J Pharm Res. 2018;10:337-40.

32. Rezaee N. Ethical challenges in cancer care: a qualitative analysis of nurses' perceptions. Res Theory Nurs Pract. 2019;33:169-82.

33. Bartnik E. Ethical challenges in genetics. J Med Liban. 2019;67:138-40.

34. Alahmad G, Aljohani S, Najjar MF. Ethical challenges regarding the use of stem cells: interviews with researchers from Saudi Arabia. BMC Med Ethics. 2020;21:1-7.

35. Alahmad G, Al-Kamli H, Alzahrani H. Ethical challenges of pediatric cancer care: interviews with nurses in Saudi Arabia. Cancer Control. 2020;27:1073274820917210.

36. Alahmad G, Richi H, BaniMustafa A, Almutairi AF. Ethical challenges related to the novel coronavirus (COVID-19) outbreak: interviews with professionals from Saudi Arabia. Front Med. 2021. https://doi.org/10. 3389/fmed.2021.620444.

37. Alahmad G, AlSaqabi M, Alkamli H, Aleidan M. Ethical challenges in consent procedures involving pediatric cancer patients in Saudi Arabia: an exploratory survey. Dev World Bioeth. 2021. https://doi.org/10.1111/ dewb.12308.

38. Bijani M, Mohammadi F. Ethical challenges of caring for burn patients: a qualitative study. BMC Med Ethics. 2021;22:1-10.

39. Bladt T, Vorup-Jensen T, Sædder E, Ebbesen M. Empirical investigation of ethical challenges related to the use of biological therapies. J Law Med Ethics. 2020;48:567-78.

40. Boulanger RF, Komparic A, Dawson A, Upshur REG, Silva DS. Developing and implementing new TB technologies: key informants' perspectives on the ethical challenges. J Bioeth Inq. 2020;17:65-73.

41. Bourbonnais A, Rousseau J, Lalonde M-H, Meunier J, Lapierre N, Gagnon M-P. Conditions and ethical challenges that could influence the implementation of technologies in nursing homes: a qualitative study. Int J Older People Nurs. 2019;14:e12266.

42. Brodtkorb K, Skisland AV-S, Slettebø A, Skaar R. Preserving dignity in end-of-life nursing home care: some ethical challenges. Nord I Nurs Res. 2017;37:78-84.

43. Bruun H, Lystbaek SG, Stenager E, Huniche L, Pedersen R. Ethical challenges assessed in the clinical ethics Committee of Psychiatry in the region of Southern Denmark in 2010-2015: a qualitative content analyses. BMC Med Ethics. 2018;19:62.

44. Canario Guzmán JA, Espinal R, Báez J, Melgen RE, Rosario PAP, Mendoza ER. Ethical challenges for international collaborative research partnerships in the context of the Zika outbreak in the Dominican Republic: a qualitative case study. Health Res Policy Syst. 2017;15:82.

45. Carnevale F, Delogu B, Bagnasco A, Sasso L. Correctional nursing in Liguria, Italy: examining the ethical challenges. J Prev Med Hyg. 2018;59:E315

46. Delpasand K, Nazari Tavakkoli S, Kiani M, Abbasi M, Afshar L. Ethical challenges in the relationship between the pharmacist and patient in Iran. Int J Hum Rights Healthc. 2020;13:317-23.

47. Donnelly S, Walker S. Enabling first and second year doctors to negotiate ethical challenges in end-of-life care: a qualitative study. BMJ Support Palliat Care. 2021. https://doi.org/10.1136/bmispcare-2020-002672.

48. Draper $\mathrm{H}$, Jenkins $\mathrm{S}$. Ethical challenges experienced by UK military medical personnel deployed to Sierra Leone (operation GRITROCK) during the 2014-2015 Ebola outbreak: a qualitative study. BMC Med Ethics. 2017:18:77.

49. Ebrahimi A, Ebrahimi S. Pediatric residents'and attending physicians' perspectives on the ethical challenges of end of life care in children. J Med Ethics Hist Med. 2018;11:16.

50. Forbes $S$, Phillips $C$. Ethical challenges encountered by clinical trials nurses: a grounded theory study. Oncol Nurs Forum. 2020;47:428-35.

51. Gágyor I, Heßling A, Heim S, Frewer A, Nauck F, Himmel W. Ethical challenges in primary care: a focus group study with general practitioners, nurses and informal caregivers. Fam Pract. 2019;36:225-30.

52. Haugom W, Ruud E, Hynnekleiv T. Ethical challenges of seclusion in psychiatric inpatient wards: a qualitative study of the experiences of Norwegian mental health professionals. BMC Health Serv Res. 2019;19:879.

53. Hawking M, Kim J, Jih M, Hu C, Yoon JD. "Can virtue be taught?": a content analysis of medical students' opinions of the professional and 
ethical challenges to their professional identity formation. BMC Med Educ. 2020;20:380.

54. Hyder A, Krubiner C. Ethical challenges in designing and implementing health systems research: experiences from the field. AJOB Empir Bioeth. 2016;7:209-17.

55. Jackson C, Gardy JL, Shadiloo HC, Silva DS. Trust and the ethical challenges in the use of whole genome sequencing for tuberculosis surveillance: a qualitative study of stakeholder perspectives. BMC Med Ethics. 2019:20:43.

56. Jakobsen R, Sørlie V. Ethical challenges: trust and leadership in dementia care. Nurs Ethics. 2016;23:636-45.

57. Jia Y, Chen O, Xiao Z, Xiao J, Bian J, Jia H. Nurses' ethical challenges caring for people with COVID-19: a qualitative study. Nurs Ethics. 2021;28:33-45.

58. Kalkman S, van Thiel GJMW, Grobbee DE, Meinecke A-K, Zuidgeest MGP, van Delden JJM, et al. Stakeholders'views on the ethical challenges of pragmatic trials investigating pharmaceutical drugs. Trials. 2016;17:419.

59. Kasper J, Mulye A, Doobay-Persaud A, Seymour B, Nelson BD. Perspectives and solutions from clinical trainees and mentors regarding ethical challenges during global health experiences. Ann Glob Health. 2020;86:34.

60. Kelley MC, Brazg T, Wilfond BS, Lengua $\sqcup$, Rivin BE, Martin-Herz SP, et al. Ethical challenges in research with orphans and vulnerable children: a qualitative study of researcher experiences. Int Health. 2016;8:187-96.

61. Kemparaj VM, Panchmal GS, Kadalur UG. The top 10 ethical challenges in dental practice in indian scenario: dentist perspective. Contemp Clin Dent. 2018;9:97.

62. Klitzman R. Unconventional combinations of prospective parents: ethical challenges faced by IVF providers. BMC Med Ethics. 2017;18:18.

63. Komparic A, Dawson A, Boulanger RF, Upshur REG, Silva DS. A failure in solidarity: ethical challenges in the development and implementation of new tuberculosis technologies. Bioethics. 2019;33:557-67.

64. Laholt H, McLeod K, Guillemin M, Beddari E, Lorem G. Ethical challenges experienced by public health nurses related to adolescents' use of visual technologies. Nurs Ethics. 2019;26:1822-33.

65. Laliberté M, Williams-Jones B, Feldman DE, Hunt M. Ethical challenges for patient access to physical therapy: views of staff members from three publicly-funded outpatient physical therapy departments. Narrat Inq Bioeth. 2017;7:157-69.

66. Larkin ME, Beardslee B, Cagliero E, Griffith CA, Milaszewski K, Mugford $M T$, et al. Ethical challenges experienced by clinical research nurses: a qualitative study. Nurs Ethics. 2019;26:172-84.

67. Mbalinda SN, Bakeera-Kitaka S, Amooti DL, Magongo EN, Musoke P, Kaye DK. Ethical challenges of the healthcare transition to adult antiretroviral therapy (ART) clinics for adolescents and young people with HIV in Uganda. BMC Med Ethics. 2021;22:1-14.

68. Mehdipour Rabori R, Dehghan M, Nematollahi M. Nursing students' ethical challenges in the clinical settings: a mixed-methods study. Nurs Ethics. 2019;26:1983-91.

69. Mlughu TS, Anaeli A, Joseph R, Sirili N. Voluntary HIV counseling and testing among commercial motorcyclist youths: an exploration of ethical challenges and coping mechanisms in Dar es Salaam. HIVAIDS - Res Palliat Care. 2020;12:675-85.

70. Moeini S, Shahriari M, Shamali M. Ethical challenges of obtaining informed consent from surgical patients. Nurs Ethics. 2020;27:527-36.

71. Naseri-Salahshour V, Sajadi M. Ethical challenges of novice nurses in clinical practice: Iranian perspective. Int Nurs Rev. 2020;67:76-83.

72. Naseri-Salahshour V, Sajadi M. From suffering to indifference: reaction of novice nurses to ethical challenges in first year of clinical practice. Iran J Nurs Midwifery Res. 2019;24:251.

73. Nicholls SG, Carroll K, Zwarenstein M, Brehaut JC, Weijer C, Hey SP, et al. The ethical challenges raised in the design and conduct of pragmatic trials: an interview study with key stakeholders. Trials. 2019;20:765.

74. Pancras G, Shayo J, Anaeli A. Non-medical facilitators and barriers towards accessing haemodialysis services: an exploration of ethical challenges. BMC Nephrol. 2018;19:342.

75. Sabone M, Mazonde P, Cainelli F, Maitshoko M, Joseph R, Shayo J, et al. Everyday ethical challenges of nurse-physician collaboration. Nurs Ethics. 2020;27:206-20.
76. Seekles W, Widdershoven G, Robben P, van Dalfsen G, Molewijk B. Inspectors' ethical challenges in health care regulation: a pilot study. Med Health Care Philos. 2017;20:311-20.

77. Segal AG, Frasso R, Sisti DA. County jail or psychiatric hospital? Ethical challenges in correctional mental health care. Qual Health Res. 2018;28:963-76.

78. Shayestefar S, Hamooleh MM, Kouhnavard M, Kadivar M. Ethical challenges in pediatrics from the viewpoints of Iranian pediatric residents. J Compr Pediatr. 2018. https://doi.org/10.5812/compreped.62747.

79. Sinow C, Burgart A, Char DS. How anesthesiologists experience and negotiate ethical challenges from drug shortages. AJOB Empir Bioeth. 2020;12:84-91.

80. Slettebø Å, Skaar R, Brodtkorb K, Skisland A. Conflicting rationales: leader's experienced ethical challenges in community health care for older people. Scand J Caring Sci. 2018;32:645-53.

81. Storaker A, Nåden D, Sæteren B. From painful busyness to emotional immunization: nurses' experiences of ethical challenges. Nurs Ethics. 2017;24:556-68.

82. Taebi M, Bahrami R, Bagheri-Lankarani N, Shahriari M. Ethical challenges of embryo donation in embryo donors and recipients. Iran J Nurs Midwifery Res. 2018;23:36.

83. Tønnessen S, Solvoll B-A, Brinchmann BS. Ethical challenges related to next of kin - nursing staffs' perspective. Nurs Ethics. 2016;23:804-14.

84. Ullrich A, Theochari M, Bergelt C, Marx G, Woellert K, Bokemeyer C, et al. Ethical challenges in family caregivers of patients with advanced cancer-a qualitative study. BMC Palliat Care. 2020;19:1-13.

85. Verma A, Smith AK, Harrison KL, Chodos AH. Ethical challenges in caring for unrepresented adults: a qualitative study of key stakeholders. J Am Geriatr Soc. 2019;67:1724-9.

86. Morley G, Ives J, Bradbury-Jones C. Moral distress and austerity: an avoidable ethical challenge in healthcare. Health Care Anal. 2019;27:185-201.

87. Ayala-Yáñez R, Ruíz-López R, McCullough LB, Chervenak FA. Violence against trainees: urgent ethical challenges for medical educators and academic leaders in perinatal medicine. J Perinat Med. 2020;48:728-32.

88. Binns $C$, Lee M, Kagawa M. Ethical challenges in infant feeding research. Nutrients. 2017:9:59.

89. Čartolovni A, Habek D. Guidelines for the management of the social and ethical challenges in brain death during pregnancy. Int J Gynecol Obstet. 2019;146:149-56.

90. Hofmann B. Informing about mammographic screening: ethical challenges and suggested solutions. Bioethics. 2020;34:483-92.

91. Hunt M, Pal NE, Schwartz L, O'Mathúna D. Ethical challenges in the provision of mental health services for children and families during disasters. Curr Psychiatry Rep. 2018;20:60.

92. Johnson S, Parker M. Ethical challenges in pathogen sequencing: a systematic scoping review. Wellcome Open Res. 2020;5:119.

93. MacDonald S, Shemie S. Ethical challenges and the donation physician specialist: a scoping review. Transplantation. 2017. https://doi.org/10. 1097/TP.0000000000001697.

94. Saigle V, Racine E. Ethical challenges faced by healthcare professionals who care for suicidal patients: a scoping review. Monash Bioeth Rev. 2018:35:50-79.

95. Saigle V, Séguin M, Racine E. Identifying gaps in suicide research: a scoping review of ethical challenges and proposed recommendations. IRB Ethics Hum Res. 2017;39:1-9.

96. Wilson E, Kenny A, Dickson-Swift V. Ethical challenges in communitybased participatory research: a scoping review. Qual Health Res. 2018;28:189-99.

97. Martins Pereira S, Hernández-Marrero P. Ethical challenges of outcome measurement in palliative care clinical practice: a systematic review of systematic reviews. Ann Palliat Med. 2018;7:S207-18.

98. Saghafi A, Bahramnezhad F, Poormollamirza A, Dadgari A, Navab E. Examining the ethical challenges in managing elder abuse: a systematic review. J Med Ethics Hist Med. 2019. https://doi.org/10.18502/ jmehm.v12i7.1115.

99. West E, Stuckelberger A, Pautex S, Staaks J, Gysels M. Operationalising ethical challenges in dementia research - a systematic review of current evidence. Age Ageing. 2017;46:678-87. 
100. Ewuoso C, Hall S, Dierickx K. How do healthcare professionals respond to ethical challenges regarding information management? A review of empirical studies. Glob Bioeth. 2021;32:67-84.

101. Schofield G, Brangan E, Dittborn M, Huxtable R, Selman L. Real-world ethics in palliative care: protocol for a systematic review of the ethical challenges reported by specialist palliative care practitioners in their clinical practice. BMJ Open. 2019;9:e028480.

102. Sun W, Wilson MG, Schreiber D, Wang RH. Ethical challenges related to assistive product access for older adults and adults living with a disability: a scoping review protocol. Syst Rev. 2017;6:24.

103. Schwartz L, Sinding C, Hunt M, Elit L, Redwood-Campbell L, Adelson N, et al. Ethics in humanitarian aid work: learning from the narratives of humanitarian health workers. AJOB Prim Res. 2010;1:45-54.

104. McConnell T. Moral Dilemmas. In: Zalta EN, editor. The Stanford Encyclopedia of Philosophy. Fall 2018. Metaphysics Research Lab, Stanford University; 2018. https://plato.stanford.edu/archives/fall2018/entries/ moral-dilemmas/. Accessed 30 Oct 2019.

105. Tessman L. Moral failure: on the impossible demands of morality. New York, NY: Oxford University Press; 2014. http://search.ebscohost.com/ login.aspx?direct $=$ true\&scope $=$ site $\& \mathrm{db}=$ nlebk $\& \mathrm{db}=$ nlabk\&AN $=$ 859724. Accessed 5 Nov 2019.

106. Ejder Apay S, Gürol A, Gür EY, Church S. Midwifery students' reactions to ethical dilemmas encountered in outpatient clinics. Nurs Ethics. 2020:27:1542-55.

107. Milliken A, Ludlow L, DeSanto-Madeya S, Grace P. The development and psychometric validation of the Ethical Awareness Scale. J Adv Nurs. 2018;74:2005-16.

108. Truog RD, Brown SD, Browning D, Hundert EM, Rider EA, Bell SK, et al. Microethics: the ethics of everyday clinical practice. Hastings Cent Rep. 2015:45:11-7
109. Woods S, Beaver K, Luker K. User's views of palliative care services: ethical implications. Nurs Ethics Int J Health Care Prof. 2000;7:314-26.

110. Morley G, Ives J, Bradbury-Jones C, Irvine F. What is 'moral distress'? A narrative synthesis of the literature. Nurs Ethics. 2017;26:646-62.

111. Epstein EG, Hamric AB. Moral distress, moral residue, and the crescendo effect. J Clin Ethics. 2009;20:330-42.

112. Mason VM, Leslie G, Clark K, Lyons P, Walke E, Butler C, et al. Compassion fatigue, moral distress, and work engagement in surgical intensive care unit trauma nurses: a pilot study. Dimens Crit Care Nurs DCCN. 2014;33:215-25

113. Jameton A. Nursing practice: the ethical issues. Englewood Cliffs: Prentice-Hall; 1984.

114. Tigard DW. The positive value of moral distress. Bioethics. 2019:33:601-8.

115. Beauchamp TL, Childress JF. Principles of biomedical ethics. New York: Oxford University Press; 1979.

116. Klingler C, Silva DS, Schuermann C, Reis AA, Saxena A, Strech D. Ethical issues in public health surveillance: a systematic qualitative review. BMC Public Health. 2017;17:295.

117. Solvoll B-A, Hall EO, Brinchmann BS. Ethical challenges in everyday work with adults with learning disabilities. Nurs Ethics. 2015;22:417-27.

\section{Publisher's Note}

Springer Nature remains neutral with regard to jurisdictional claims in published maps and institutional affiliations.
Ready to submit your research? Choose BMC and benefit from:

- fast, convenient online submission

- thorough peer review by experienced researchers in your field

- rapid publication on acceptance

- support for research data, including large and complex data types

- gold Open Access which fosters wider collaboration and increased citations

- maximum visibility for your research: over 100M website views per year

At BMC, research is always in progress.

Learn more biomedcentral.com/submissions 